\title{
ANALISIS KELAYAKAN RUTE PENERBANGAN JOGJAKARTA-BANJARMASIN-JOGJAKARTA DENGAN PESAWAT B-737 SERI 200
}

\author{
Rahimudin \\ Sekolah Tinggi Teknologi Kedirgantaraan \\ e-mail: rachiem96@yahoo.com
}

\begin{abstract}
ABSTRACK
Yogyakarta-Banjarmasin-Yogyakarta was very potential route for airlines to select as their planning route selection because of demand of both city has growth significantly. This new route selection becomes very important as research material because it can determine a company's cost advantage in taking the existing market potential. Until now, only Lion Air has established with this route and gets the profit significantly. The aims of this case study was to determine the feasibility of these airlines Yogyakarta-Banjarmasin-Yogyakarta based on analysis of airport operations, demand of passenger in both sectors and also analyze operational costs by using the model of demand of passenger aircraft Yogyakarta-Banjarmasin-Yogyakarta. Passenger demand equation model is determined by analyzing the historical data of passenger demand Yogyakarta-Banjarmasin-Yogyakarta through multiple linear regression method. Equation model was developed to estimate the number of annual passenger demand Yogyakarta-Banjarmasin-Yogyakarta as independent variables and the dependent variable is the total number of passengers in Yogyakarta-BanjarmasinYogyakarta, PDRB (Product Domestics Regional Brutto) and also income per capita. Keywords: route Yogyakarta-Banjarmasin-Yogyakarta, break even point
\end{abstract}

\section{PENDAHULUAN}

Pada dasarnya Airlines yang kompetitif sebagai Airlines utama pilihan konsumen dibagi atas dua variabel penting, pertama adalah variabel utama terdiri atas Harga, Jadwal penerbangan dan Rute penerbangan. Kedua adalah variable tambahan terdiri atas Frekwensi, Service, Equipment, Loyalitas, Persepsi dan Convenience.

Harga, menjadi hal yang sangat penting karena hal ini berkaitan dengan daya beli masyarakat. Penentuan tarif pada tiap rute penerbangan sangat dipengaruhi oleh biaya operasional penerbangan tersebut baik itu biaya operasional langsung dan biaya operasional tak langsung. Peng- hematan pada biaya operasional ini akan menambah daya saing pada penentuan harga tiap rute.

Kedua Jadwal Penerbangan, pemilihan jadwal penerbangan yang tepat ditandai dengan pemilihan waktu perjalanan pada tiap rute yang diterbangi. Tiap-tiap daerah memiliki karakteristik perjalanan yang berbeda-beda. Karakteristik ini dipengaruhi oleh jenis pekerjaan mayoritas yang digeluti oleh penduduk daerah tersebut dan keunggulan yang dimilikinya.

Hal yang tak kalah penting adalah Rute penerbangan. Dalam Industri Penerbangan jaringan rute (route network) adalah hal yang sangat vital. Dengan adanya deregulasi aturan penerbangan sistem rute ini menjadi salah satu 
variabel yang kompetitif. Biaya pembukaan rute yang tinggi akan menyulitkan suatu Airlines dalam mendeterminasi pasar untuk bersaing dengan kompetitor yang sudah ada. Untuk itu perlu adanya kajian analisis yang mendalam pada saat pembukaan jaringan rute baru.

Analisis yang diperlukan dalam pembukaan jaringan rute baru dapat meliputi: Volume dan potensi pasar, daya beli pasar, persaingan, tingkat daya dukung bandara, tarif, biayabiaya langsung operasional penerbangan, rotasi pesawat, lama penerbangan/flight time, utilisasi pesawat, crew rotation, Maksimum landing per hari. Faktor - faktor tersebut sangat berpengaruh terutama untuk memprediksi market share yang bisa didapat.

Tujuan penelitian ini adalah, pertama mengetahui kelayakan rute penerbangan Yogyakarta-Banjarmasin dan Banjarmasin-Yogyakarta berdasarkan analisa operasi, permintaan penumpang dan biaya penerbangan. Kedua menganalisis faktor-faktor yang mempengaruhi pembukaan rute penerbangan baru yaitu PDRB per kapita, pendapatan perkapita, permintaan penumpang dalam 10 tahun terakhir. Ketiga menjadi acuan dalam menganalisis rute penerbangan baru berdasarkan faktor-faktor yang mempengaruhinya. Tujuan keempat adalah dalam membuka rute penerbangan baru perusahaan penerbangan menjadi lebih tajam khususnya dalam melakukan analisa sehingga keputusan yang diambil menjadi lebih berbobot.

\section{REVIEW LITERATUR DAN HIPOTESIS}

Dalam pemilihan pola jaringan penerbangan perlu mempertimbangkan 3 aspek:

1. Aspek geografis

2. Aspek pembangunan nasional dan daerah. Pada prinsipnya strategi pembangunan nasional dan daerah menerapkan pola dengan komponen pusat dan sub pusat pertumbuhan untuk mencapai konvergasi dari tingkat ke- majuan pembangunan antar daerah atau antar wilayah. Dengan mengunakan starategi tersebut diharapkan tingkat kemajuan pembangunan yang terdapat pusat dapat dijalankan ke subpusat yang selanjutnya dijalankan wilayah cakupan subpusat. Sebaliknya, subpusat diharapkan dapat mendukung pembangunan dipusat.

3. Aspek keadaan jaringan penerbangan saat ini. Pola jaringan penerbangan yang terjadi saat ini merupakan campuran dari pola hub and spoke relatif mendominasi dari pola jaringan penerbangan yang ada saat ini. Kebijaksanaan pemerintah dalam pengembangan jaringan dan rute berperan mengatur keseimbangan antara penawaran dan permintaan.

Pembuatan jaringan penerbangan merupakan tahapan yang sangat penting dalam perencanaan transportasi karena dapat mempengaruhi efisiensi sarana dan prasarana serta tingkat pelayanan penumpang angkutan udara.

Dalam membuat dan mengevaluasi jaringan penerbangan digunakan beberapa paramater yang sangat berkaitan, tetapi berbeda kepentingan antara perusahaan, penumpang, dan pemerintah sebagai kebijaksanaan. Parameter jaringan penerbangan adalah frekwensi, L/F, Seat-Nm, Utilitas pesawat, dan pendapatan.

Prioritas kepentingan parameter jaringan penerbangan bagi airline, penumpang, dan pemerintah adalah sebagai berikut:

1. Bagi airline: pendapatan, L/F utilisasi, frekwensi, dan seat-Nm

2. Bagi pemakai (penumpang):Frekwensi, pendapatan, seat- $\mathrm{Nm}, \mathrm{L} / \mathrm{F}$, dan utilisasi

3. Bagi pemerintah: Frekwensi, L/F, pendapatan, utilisasi, dan seat-Nm

Untuk mengestimasi kebutuhan jasa angkutan udara yang didasarkan pada peramalan (Traffic Forecast) pada setiap rute penerbangan. Kemudian ditentukan jaringan penerbangan, besarnya kapasitas armada yang dibutuhkan, penentuan skedul penerbangan dan akhirnya 
ditentukan rencana pokok produksi sebagai pedoman dalam besarnya volume jasa angkutan udara yang akan dihasilkan.

1. Peramalan (Traffic Forecast)

Besarnya ramalan angkutan udara pada setiap rute penerbangan berguna untuk mengetahui besarnya arus penumpang dan barang. Dengan demikian akan dapat ditentukan jumlah penerbangan, jumlah seat pada setiap rute, frekuensi penerbangan, pangsa pasar, dan tingkat pelayanan yang akan diberikan.

Permintaan transportasi bersifat turunan (Derived Demand) sebagai akibat untuk memenuhi tujuan atau kebutuhan lainnya. Pada dasarnya, permintaan angkutan diakibatkan oleh :

a. Kebutuhan manusia untuk bepergian ke lokasi lain dengan tujuan mengambil bagian didalam suatu kegiatan, misalnya bekerja, berbelanja, ke sekolah, dan lainlain.

b. Kebutuhan angkutan barang untuk dapat digunakan atau dikonsumsi.

Di dalam memperkirakan permintaan angkutan di antara dua tempat, maka ada beberapa faktor yang harus dipertimbangkan :

a. Maksud Perjalanan

b. Karakteristik tempat asal yang akan mempengaruhi besarnya lalu lintas yang akan dibangkitkan, misalnya pendapatan per kapita, mobilitas penduduk dan sebagainya.

c. Karakteristik tempat tujuan yang akan mempengaruhi besarnya lalulintas yang ditarik, misalnya kemudahan, daya tarik, tersedianya fasilitas yang cukup dan sebagainya.

d. Tarif dan pelayanan transportasi yang menghubungkan kedua tempat tersebut.

Beberapa metode peramalan yang sesuai untuk angkutaqn udara adalah sebagai berikut:

1. Model Eksponensial ( $\left.\mathrm{Y}=\mathrm{ab}^{\mathrm{x}}\right)$

Model ini digunakan jika variabel yang ter- gantung pada yang lain memperlihatkan laju pertumbuhan yang konstan terhadap waktu. Gejala ini sering terjadi dalam dunia penerbangan, terutama untuk proyeksi-proyeksi tingkat kegiatan yang memperlihatkan kecenderungan jangka panjang meningkat atau menurun dengan persentase tahunan ratarata.

2. Model Linear $(Y=a+b x)$

Model ini digunakan untuk pola permintaan yang menunjukkan suatu hubungan linear dengan perubahan waktu. Hubungan yang mendasarinya mungkin konstan atau berubah dengan pola yang teratur, musiman, atau siklus.

3. Model Logistik $(1 / y=a+b x)$

Model ini digunakan bila laju pertumbuhan tahunan rata-rata secara berangsur-angsur berkurang sesuai dengan waktu. Dengan timbulnya pasar penerbangan sering terjadi periode awal dengan pertumbuhan tahunan yang terus menerus meningkat, periode pertengahan dengan pertumbuhan yang konstan, dan akhir periode dengan pertumbuhan menurun sampai terjadi kejenuhan pasar.

Model yang akan dipilih adalah yang akan memberikan angka presisi terbaik, yaitu yang memiliki angka koefisien korelasi terbesar, serta angka mean square error terkecil.

Koefisien Korelasi $(\mathrm{X})=$

$$
\frac{n \sum x y \pm \sum x \sum y}{\left.\left.\sqrt{\left\{n \sum x_{2}-\left(\sum x\right)^{2}\right.}\right\}^{n} \sum y^{2} \pm\left(\sum y\right)^{2}\right\}}
$$

Dan Mean Square Error (MSE) =

$$
\sqrt{\frac{\sum(y-y+)^{2}}{n}}
$$

Keterangan :

$$
\begin{aligned}
& \mathrm{x}=\text { Variabel Bebas } \\
& \mathrm{y}=\text { Variabel tak Bebas } \\
& \mathrm{y}^{2}=\text { Forecast } \\
& \mathrm{n}=\text { Jumlah Periode }
\end{aligned}
$$


Struktur rute dibedakan atas rute utama (trunk routes) serta rute umpan (feeder routes) dan rute perintis. Yang termasuk dalam rute utama memiliki cirri-ciri sebagai berikut :

a. Jarak yang Jauh (Lebih dari 500 mil)

b. Menghubungkan kota besar (dari Hub ke Hub)

c. Muatannya besar $( \pm 100 \mathrm{pax} /$ rute/ hari atau 400.000 pax / tahun ). Rute umpan minimal $14.000 \mathrm{pax}$ / tahun) penerbangan dari spoke ke hub dalam zona yang sama.

\section{METODE PENELITIAN}

\section{Materi Penelitian}

Data yang diperlukan dalam penelitian ini adalah:

1. Data Primer

a. Rencana Penerbangan (Flight Plan) JOGBDJ yang merupakan data-data yang harus dikerjakan oleh penerbang sebelum melakukan penerbangan pada setiap rute yang dilalui. Rencana penerbangan berisi secara detail tentang waktu tempuh penerbangan JOG-BDJ, Bahan bakar yang digunakan dalam penerbangan tersebut termasuk untuk bahan bakar menuju rute alternatif, check point yang harus dilalui oleh setiap penerbangan dalam melakukan penerbangan pada rute JOGBDJ. Selain data tersebut juga terdapat data Bandar Udara tujuan pesawat yang digunakan dan kecepatan pesawat yang digunakan.

b. Rencana Penerbangan (Flight Plan) BDJ-JOG BDJ yang merupakan datadata yang harus dikerjakan oleh penerbangan sebelum melakukan penerbangan pada setiap rute yang dilalui. Rencana penerbangan berisi secara detail tentang waktu tempuh penerbangan BDJ-JOG, Bahan bakar yang digunakan dalam penerbangan tersebut termasuk untuk bahan bakar menuju rute alternatif, chek point yang harus dilalui oleh setiap penerbangan dalam melakukan penerbangan pada rute BDJ-JOG. Selain data tersebut juga terdapat data Bandar Udara tujuan pesawat yang digunakan dan kecepatan pesawat yang digunakan.

c. Biaya Operasional Pesawat Boeing 737 seri 200 yang merupakan biaya total antara biaya langsung dan biaya tidak langsung pada penerbangan rute JOGBDJ-JOG. Biaya operasional tercatat dalam nilai dollar US yang merupakan standar biaya penerbangan internasional pada saat ini

2. Data Sekunder

a. Potensial Market penumpang pesawat udara di Bandar Udara Adisutjipto, dan Banjarmasin 10 tahun terakhir.

Potensial market penumpang pesawat udara di Bandar Udara Adisucipto dan Bandar Udara Syamsudin Noor dilakukan dengan mengambil data 10 tahun terakhir sejak tahun 1988 sampai 2003. Data penumpang tahun 1998 sampai dengan 2002 tidak dimasukkan karena data tersebut mengalami anomali akibat krisis ekonomi di Indonesia.

b. Produk Domestik Regional Brutto (PDRB) per Kapita Propinsi Banjarmasin dan Yogyakarta 10 tahun terakhir

Merupakan pendapatan daerah kotor pada kondisi harga konstan dibagi jumlah penduduk daerah setempat. PDRB perkapita mencerminkan kemampuan daerah tersebut dapat melaksanakan roda perekonomian yang dijalankan oleh masyarakat.

c. Jumlah Penduduk DIY dan Kalimantan Selatan 10 tahun terakhir

Jumlah penduduk memiliki laju pertumbuhan yang konstan naik. Data jumlah penduduk yang bertambah dapat pula mencerminkan bertambahnya kemam- 
puan ekonomi masyarakat sehingga menyebabkan pertumbuhan penumpang pesawat udara juga mengalami peningkatan.

d. Pendapatan Per Kapita DIY dan Kalimantan Selatan 10 tahun terakhir Pendapatan perkapita adalah kemampuan atau pendapatan masyarakat keseluruhan pada satu daerah tertentu. Pendapatan perkapita berarti pendapatan seluruh penduduk dibagi jumlah total penduduk tersebut.

\section{HASIL PENELITIAN DAN PEMBAHASAN}

\section{Analisis Permintaan Penumpang Rute jog- bdj-jog}

Penerbangan langsung (direct flight) JOG-BDJ merupakan rute potensial yang sampai saat ini belum diterbangi oleh perusahaan jasa penerbangan komersial, padahal potensial market JOG-BDJ-JOG sangat tinggi dan belum tergarap.

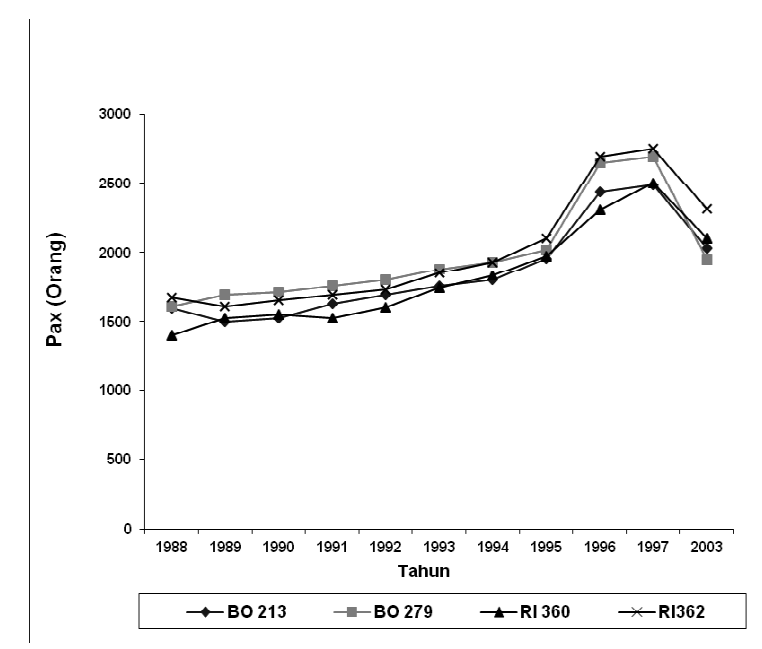

\section{Gambar 1}

Pax SUB-BDJ yang membeli tiket di JOG

Total penumpang SUB-BDJ pada tahun 1988 berjumlah 6.275 orang yang dilayani oleh dua penerbangan komersial yaitu Bouraq Airlines dan Mandala Airlines. Bouraq Airlines memperoleh penumpang 50,9\% dan Mandala
Airlines memperoleh 49,1\%. Mulai tahun 1988 sampai dengan tahun 1997 terjadi kenaikan penumpang sebesar $66,1 \%$ menjadi 10.427 orang. Kenaikan penumpang pesawat udara tujuan JOG-BDJ-JOG disebabkan terjadinya aktivitas perdagangan yang meningkat antar kedua daerah tersebut. Selain itu Aktivitas pendidikan pemudapemudi Banjarmasin yang melanjutkan jenjang pendidikan di Yogyakarta.

Mulai tahun 1998 sampai dengan 2002 jumlah penumpang JOG-BDJ via SUB tidak dapat ditampilkan karena terjadi anomali pergerakan penumpang. Hal ini disebabkan oleh krisis multi dimensi yang melanda Indonesia selama 5 tahun dan kembali pulih mulai tahun 2003. Potensi penumpang pesawat udara JOG-BDJ sangat besar dan setiap tahunnya mengalami peningkatan jumlah penumpang. Kesempatan ini merupakan peluang bagi perusahaan penerbangan komersial khususnya PT. Bouraq Indonesia Airlines untuk membuka rute penerbangan baru JOG-BDJ-JOG langsung tanpa transit di Bandar Udara Surabaya.

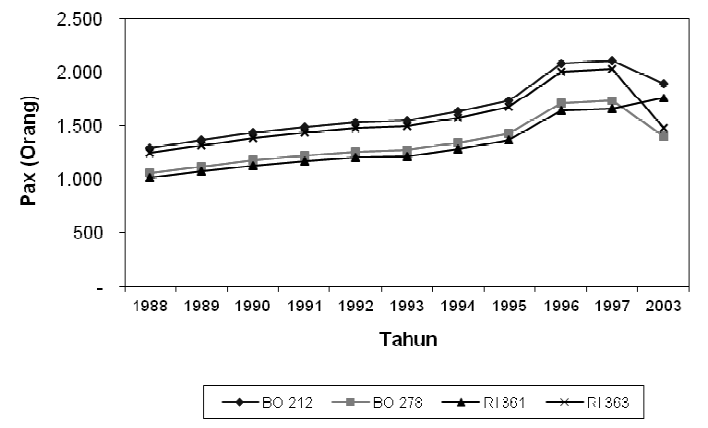

\section{Gambar 2}

Pax BDJ-SUB yang membeli tiket di JOG

Total penumpang BDJ-JOG pada tahun 1988 berjumlah 4.627 orang yang dilayani oleh dua penerbangan komersial yaitu Bouraq Airlines dan Mandala Airlines. Bouraq Airlines memperoleh penumpang $51 \%$ dengan perincian BO212 mendapat $28 \%$ dan BO 287 mendapat 
23\% sementara Mandala Airlines memperoleh $49 \%$ dengan perincian RI 361 mendapat $25 \%$ dan RI 363 mendapat 21\%. Mulai tahun 1988 sampai dengan tahun 1997 terjadi kenaikan penumpang sebesar $61,4 \%$ dari 4.627 orang menjadi 7.540 orang. Kenaikan penumpang pesawat udara tujuan JOG-BDJ-JOG disebabkan terjadinya aktivitas perdagangan yang meningkat antar kedua daerah tersebut. Selain itu Aktivitas pendidikan pemuda-pemudi Banjarmasin yang melanjutkan jenjang pendidikan di Yogyakarta. Pada tahun 2002 PT Lion Air mulai membuka penerbangan baru sehingga ikut mempertajam kompetisi penerbangan. Tahun 2003 Lion Air berhasil mendapat 7\% dari total market yang ada sedangkan Bouraq Airlines mendapat 48\% dan Mandala Airlines mendapat 46\%.

Hasil analisa memperlihatkan bahwa hubungan antara kelayakan rute penerbangan JOG-BDJ dengan PDRB, Pendapatan perkapita dan jumlah penumpang memperlihatkan persamaan regresi berganda:

$Y=786+2,54 \cdot 10^{-4} X_{1}+4,57 \cdot 10^{-4} X_{2}+2,57 \cdot 10^{-4} X_{3}$ Dimana :

$\mathrm{Y}=$ Kelayakan Rute JOG-BDJ ( Perkembangan Penumpang JOG-BDJ via SUB)

$\mathrm{X}_{1}=$ PDRB Perkapita JOG

$\mathrm{X}_{2}=$ Jumlah Penumpang Pesawat Udara JOG

$\mathrm{X}_{3}=$ Pendapatan Perkapita JOG

Hasil analisa berdasarkan regresi linear berganda BDJ-JOG dengan variabel bebas PDRB per kapita, Pendapatan per kapita dan jumlah penumpang BDJ dapat dinyatakan sebagai berikut:

$Y=1.082+5,13 \cdot 10^{-4} \mathrm{X}_{1}+1,10.10^{-4} \mathrm{X}_{2}+2,35.10^{-4} \mathrm{X}_{3}$ Dimana :

$\mathrm{Y}=$ Kelayakan Rute BDJ-JOG ( Perkembangan Penumpang BDJ-JOG via SUB)

$\mathrm{X}_{1}=$ PDRB Perkapita BDJ
$\mathrm{X}_{2}=$ Jumlah Penumpang Pesawat Udara BDJ

$\mathrm{X}_{3} \quad=$ Pendapatan Perkapita BDJ

Tabel 1

Forecasting pertumbuhan penumpang JOGBDJ sampai tahun 2014

\begin{tabular}{|c|c|c|c|c|}
\hline & Demand Pax & PDRB & PAX Total & Income \\
\hline & Y (Orang) & $\mathrm{X}_{1}$ (Rupiah) & $\mathrm{X}_{2}$ (Orang) & $\mathrm{X}_{3}$ (Rupiah) \\
\hline 2004 & 12,585 & 1.859 .389 & 1.643 .428 & 1.616 .414 \\
\hline 2005 & 15,128 & 1.983 .968 & 1.824 .205 & 1.711 .621 \\
\hline 2006 & 17,820 & 2.116 .894 & 2.024 .868 & 1.812 .435 \\
\hline 2007 & 20,675 & 2.258 .726 & 2.247 .603 & 1.919 .188 \\
\hline 2008 & 23,709 & 2.410 .060 & 2.494 .840 & 2.032 .228 \\
\hline 2009 & 26,937 & 2.571 .535 & 2.769 .272 & 2.151 .926 \\
\hline 2010 & 30,378 & 2.743 .827 & 3.073 .892 & 2.278 .675 \\
\hline 2011 & 34,051 & 2.927 .664 & 3.412 .020 & 2.412 .888 \\
\hline 2012 & 37,979 & 3.123 .817 & 3.787 .342 & 2.555 .008 \\
\hline 2013 & 42,185 & 3.333 .113 & 4.203 .950 & 2.705 .498 \\
\hline 2014 & 46,696 & 3.556 .432 & 4.666 .385 & 2.864 .851 \\
\hline
\end{tabular}

Tahun 2004 jumlah penumpang sebanyak JOG-BDJ 12.585 orang dan berdasarkan forecasting sampai tahun 2014 jumlah penumpang adalah 46.696 orang. Load factor yang didapatkan pada tahun 2004 adalah $42 \%$ sementara untuk tahun 2014 adalah mencapai 156\% atau dibutuhkan dua pesawat Boeing 737 seri 200. Penumpang yang dapat dihasilkan pada tahun 2005 adalah 51 orang setiap harinya dengan asumsi pesawat beroperasi selama 300 hari atau dengan kata lain load factor mencapai 50\% dari kapasitas tempat duduk yang ada 
Tabel 2

Forecasting pertumbuhan penumpang BDJJOG sampai tahun 2014

\begin{tabular}{|c|c|c|c|c|}
\hline & Demand Pax & PDRB & PAX Total & Income \\
\hline & Y (Orang) & $\mathrm{X}_{2}$ (Rupiah) & $\mathrm{X}_{2}($ Orang) & $\mathrm{X}_{3}$ (Rupiah) \\
\hline 2004 & 10,142 & 2.454 .681 & 1.104 .603 & 1.937 .804 \\
\hline 2005 & 13,361 & 2.595 .580 & 1.226 .109 & 2.043 .414 \\
\hline 2006 & 16,707 & 2.744 .566 & 1.360 .981 & 2.154 .780 \\
\hline 2007 & 20,189 & 2.902 .104 & 1.510 .689 & 2.272 .216 \\
\hline 2008 & 23,816 & 3.068 .685 & 1.676 .864 & 2.396 .052 \\
\hline 2009 & 27,596 & 3.244 .828 & 1.861 .320 & 2.526 .637 \\
\hline 2010 & 31,539 & 3.431 .081 & 2.066 .065 & 2.664 .338 \\
\hline 2011 & 35,655 & 3.628 .025 & 2.293 .332 & 2.809 .545 \\
\hline 2012 & 39,956 & 3.836 .273 & 2.545 .598 & 2.962 .665 \\
\hline 2013 & 44,454 & 4.056 .475 & 2.825 .614 & 3124.130 \\
\hline 2014 & 49,161 & 4.289 .317 & 3.136 .432 & 3.294 .395 \\
\hline
\end{tabular}

Kondisi ini harus dimanfaatkan secara optimal oleh perusahaan penerbangan komersial untuk membuka peluang pasar yang sangat potensial mengingat persaingan dalam industri jasa penerbangan komersial sangat ketat dan dibutuhkan analisis yang mendalam karena termasuk bisnis dengan investasi yang sangat besar. Peluang yang terbuka lebar dan kondisi perekonomian Indonesia yang telah kembali normal akan mendorong dunia usaha menjadi bergairah dan pada akhirnya kebutuhan akan moda transportasi khususnya yang memiliki kelebihan kecepatan waktu dan tarif yang kompetitif akan menjadi pilihan masyarakat untuk memenuhi kebutuhan untuk melakukan mobilitasnya.

\section{Lama Waktu Penerbangan Rute JOG-BDJ- JOG}

Dalam menganalisa lama penerbangan rute Penerbangan JOG-BDJ-JOG terbagi atas dua penerbangan yaitu JOG-BDJ dan BDJJOG. Untuk penerbangan rute JOG-BDJ total waktu penerbangan adalah 1 jam 4 menit, waktu penerbangan ini dapat diprediksikan pada masing-masing check point sehingga dapat diketahui berapa lama waktu yang dibutuhkan antar chek point dan waktu total penerbangan tersebut. Tabel dibawah ini memperlihatkan waktu tempuh dalam penerbangan JOG-BDJ. Total waktu tempuh adalah 1 jam 04 menit dan melalui 8 (delapan) chek point.

Rute Penerbangan BDJ-JOG waktu penerbangan yang ditempuh tidak jauh berbeda dengan rute penerbangan JOG-BDJ. Perbedaan total waktu penerbangan hanya 1 menit. Total waktu penerbangan BDJ-JOG adalah 1 (satu) jam 3 menit. Perbedaan check Point terjadi pada daerah Blora dan Ropia, untuk JOG-BDJ setelah melewati Purwo menuju ke Blora sedangkan rute BDJ-JOG setelah melewati Ikapi menuju ke Ropia.

\section{Bahan Bakar yang dibutuhkan Rute Penerbangan JOG-BDJ-JOG}

Pembagian bahan bakar terdiri atas, Trip fuel (Climb, Cruise, Descent, Take Off and Approach), Burn Fuel (Trip Fuel + Taxi), Contigency $5 \%$ Fuel, Alternate Fuel, Holding Fuel dan Block Fuel. Satuan yang digunakan adalah $\mathrm{Kg}$ dan dapat di konversi menjadi satuan Liter. Total bahan bakar yang dibutuhkan adalah 7.984 Kg, dengan perincian bahan bakar sebagai berikut:

1. $\quad$ Trip Fuel $=$ Climb + Cruise + Descent + Take Off and Approach

$$
\begin{aligned}
& =1.925+1.055+400+90 \\
& =3.470 \mathrm{Kg}
\end{aligned}
$$

$$
\text { 2. Burn Fuel } \begin{aligned}
&=\text { Trip Fuel }+ \text { Taxi Fuel } \\
&=3.470+200 \\
&=3.670 \mathrm{Kg}
\end{aligned}
$$

3. Block Fuel $=$ Burn Fuel + Contigency 
Fuel 5\% + Alternate Fuel + Holding Fuel

$$
\begin{aligned}
& =3.670+174+2.070+2.070 \\
& =7.984 \mathrm{Kg}
\end{aligned}
$$

Bahan bakar untuk rute Penerbangan BDJ-JOG dapat dijelaskan sesuai dengan rencana penerbangan BDJ-JOG. Total bahan bakar yang dibutuhkan adalah $7.918 \mathrm{Kg}$. Bahan bakar yang dibutuhkan lebih sedikit $66 \mathrm{Kg}$ dibandingkan rute JOG-BDJ. Dengan perincian bahan bakar sebagai berikut:

1. Trip Fuel $=$ Climb + Cruise + Descent + Take Off and Approach

$$
\begin{aligned}
& =1.850+1.123+397+90 \\
& =3.460 \mathrm{Kg}
\end{aligned}
$$

2. Burn Fuel $=$ Trip Fuel + Taxi Fuel

$$
\begin{aligned}
& =3.460+200 \\
& =3.660 \mathrm{Kg}
\end{aligned}
$$

3. Block Fuel = Burn Fuel + Contigency Fuel 5\% + Alternate Fuel + Holding Fuel

$$
\begin{aligned}
& =3.660+173+2.015+2.070 \\
& =7.918 \mathrm{Kg}
\end{aligned}
$$

Biaya Operasi Langsung Pesawat Terbang B-737 200 rute JOG-BDJ dan BDJ-JOG diperhitungkan berdasarkan Rumus berikut ini:

DOC $/$ FLT $=$ Crew Cost + Fuel \& Oil Cost + Insurance Cost + Airframe Labor Cost + Airframe Material Cost + Engine Labor Cost + Engine Material Cost + Maintenance Burden + Depreciation

$=100+594+98,3+188,9+$ $156,04+349,9+508,6+357,7+$ 480

$=\$$ US 2833,4

Biaya Operasi Tidak Langsung diperhi- tungkan berdasarkan rumus dibawah ini

IOC / SLT System Cost + Local Cost +
Aircraft Control Cost + Cabin
Attendant + Cost of Food +
Passenger Handling Cost +
Other Passenger Service Cost
+ Freight Commision and
Advertising Cost + General and
Administrative Cost
$=42.1+6.15+25.6+198.9+$
$9.9+71.28+56.13$
$=\$$ SUS 410,06

\section{KESIMPULAN DAN SARAN}

\section{Kesimpulan}

Hasil yang diperoleh dari analisa permintaan penumpang rute penerbangan JOGBDJ-JOG didapatkan hasil untuk JOG-BDJ load factor rata-rata adalah sebesar $42 \%$ dan untuk rute penerbangan BDJ-JOG adalah 45\% . Hal ini berarti sudah dapat dilakukan pembukaan rute penerbangan baru JOG-BDJ-JOG. Berdasarkan Break Even Point Rute penerbangan ini jumlah penumpang yang menyamai BEP dengan tarif pasar sebesar $\mathrm{Rp} 711.000,-$ adalah 41\%. Bila digabungkan rute JOG-BDJ-JOG maka sudah dapat memperoleh keuntungan (Profit) Rp.6.399.000 untuk rute JOG-BDJ dan untuk rute BDJ-JOG adalah Rp.13.509.000,-

Bila analisa yang digunakan menggunakan tarif sub class maka load factor yang harus terpenuhi adalah $60 \%$ sehingga rute penerbangan ini baru layak diterbangi secara komersial pada tahun 2006 karena jumlah penumpang telah mencapai 17.820 orang atau $60 \%$ dari kapasitas tempat duduk yang tersedia pada rute JOG-BDJ dan untuk rute BDJ-JOG $B E F$ terjadi pada tahun 2007 dengan jumlah penumpang 20.189 orang atau load factor $67 \%$.

Hasil analisis operasi rute penerbangan JOG-BDJ-JOG didapatkan bahwa lama waktu penerbangan untuk rute ini adalah 1 janm 04 
menit dan total waktu tempuh adalah 2 jam 8 menit. Bahan bakar yang dibutuhkan adalah sebanyak $7.984 \mathrm{Kg}$ untuk fuel onboard dan trip fuel sebanyak $3.470 \mathrm{Kg}$.

\section{Saran}

Untuk penelitian berikutnya peneliti menyarankan agar mencari faktor-faktor lain yang dapat mempengaruhi pertumbuhan rute penerbangan baru JOG-BDJ-JOG.

Disarankan pula menggunakan metode kuisioner stated preference dalam melakukan penelitian untuk mengetahui faktor-faktor lain yang mempengaruhi pembukaan rute baru JOGBDJ-JOG.

Untuk memperoleh data yang cepat dan akurat hendaknya ada kerjasama antara pihak Universitas dengan instansi terkait sehingga memudahkan untuk memperoleh data yang diinginkan sesuai dengan penelitaian yang sedang dikerjakan.

\section{DAFTAR PUSTAKA}

Airline Merpati, 2001," Pengembangan Policy Decision Tool untuk Peningkatan Kinerja Perusahan Penerbangan Indonesia dalam menghadapi Globalisasi dan Deregulasi Angkutan Udara",Jakarta.

Algifari, 1997, "Analisis Regresi (Teori, kasus, dan solusi)", Edisi Pertama, BPFE, Yogyakarta.

Alexander T.Wells, 1980, "Air Transportation A Management Perspective” ,Mc. GrawHill, New York.

Ashford, N. dan Wright, P. H.,1991. “Airport Engineering”, Third Edition, John Willey \& Sons, Inc., New York.

Ashford, N., Stanton, M.H.P., dan More, C.A.,1995, "Airport Operation", Second

Edition, McGraw-Hill, Inc., New York.

Banfe, F. Charles, 1992, "Airline Management", Prentice-Hall, Inc,New Jersey. Demsey, P.S., Dr.,2000,

Airport Planning and Development Hanbook", A
Global Survey, McGraw-Hill, Inc., New York.

Donald R.Cooper, Pamela S.Schindler, 2000, "Business Research Methods", Mc

Graw-Hill, New York.

Fathurahman, 2000, "Prospek Usaha Penerbangan Domestik Berjadual Di Indonesia", Journal Managemen Transportasi Edisi No.04/Juli 2000, Sekolah Tinggi Managemen Transportasi Udara Trisakti, Jakarta.

Kansil, C. dan Simarmata, 2001, "Kajian Perkembangan Angkutan Udara Niaga di Indonesia", Journal Managemen Transportasi Edisi No.01/Oktober 2001, Sekolah Tinggi Managemen Transportasi Udara Trisakti, Jakarta.

Khoosnulfitdiyah, U., 2001,'P Persepsi Penumpang Terhadap Terhadap Kualitas Pelayanan Pesawat Udara", Tugas Akhir, Jurusan Teknik Sipil Universitas Gajah Mada, Yogjakarta.

Nasution, 1996, "Manajemen Transportasi", Ghalia Indonesia, Jakarta.

Nojorono, O., 1990," Kajian Teoritik Pengaruh Waktu Perjalanan Terhadap Jumlah Pemakai Jasa Angkutan Umum" : Sebuah Studi Kasus, Media Teknik Edisi No.I Tahun XII Edisi April 1990, Fakultas Teknik Universitas Gajah Mada, Yogyakarta.

Ricardianto P. Ricky, 2000, "Strategi Operasional Perusahaan Penerbangan Dalam Persaingan Global", Journal Managemen Transportasi Edisi No.04/Juli 2000, Sekolah Tinggi Managemen Transportasi Udara Trisakti, Jakarta.

Permain, D., dan Kroes, E., 1990," State Preference : A Guide to Practise", steer Davies \& Gleave Ltd. London Hague Consultancy Group, Deen Haag The Netherland.

Radnoti George,2002, “ Profit Strategies For Air 
Transportation", McGraw-Hill, Inc., New York.

Santoso, Singgih, 2001, “SPSS Versi 10 : Mengolah Data Statistik Secara Profesional, Elek Media Komputindo, Jakarta.

Wells, A. T., 2000, "Airport Planning and
Management", $4^{\text {th }}$ Edition, McGrawHill, New York. 